Sylwia Kulczyk

\title{
LANDSCAPE BOUNDARIES - BELTS OR LINES? EXAMPLES FROM SOUTHERN AND NORTHERN POLAND
}

\begin{abstract}
The problem of width of landscape boundary remains widely discussed from more then one century. The author attempts to describe a width of some landscape boundaries of a higher rank by describing the mosaic of a lower rank landscape units. The research was realised within upland landscape of Nida Basin and lowland landscape of Wigry National Park.
\end{abstract}

Key words: boundary, landscape unit, landscape typology.

\section{INTRODUCTION}

The character of landscape boundaries is investigated from more, then one century. One of the widely discussed problems is a width of a boundary. Two main approaches exist, describing a boundary as a line or as a belt. Some authors attempted to co-ordinate a width of a boundary with its rank. According to Widacki (1979) boundaries of the simplest units are lines, and boundaries of units of higher rank are always built from the units of lower rank. higher is rank of a boundary, more complicated is its internal structure. A correspondence between boundary's width and its rank is clear also for Yurenkov (1982). However, Richling (1992) underlines a lack of dependence between a width or an internal structure of a boundary and the taxonomic rank of separated units. An existence of some very sharp boundaries that separate landscape units of the high rank is pointed out. Such a boundaries are often an effect of sudden change of geological features due to tectonic or erosion activity.

\section{METHODS}

\section{THE RESEARCHED AREA}

The research was made at two fields of comparable area. According to polish landscape's natural typology (Kondracki and Richling, by Richling 1992), two classes of landscape are represented: the landscape of uplands and low mountains (called further the upland's landscape) and the landscape of lowlands.

The upland area is located near Chroberz. According to the regional division of Poland (Kondracki 1986) it consists of fragments of three mesoregions. 
The central part lies within River Nida Valley (342.25) which borders with Hunch of Wodzisław (342.24) to the west and Solec Basin (342.26) to the east. According to the previously mentioned typology of the natural landscape in Poland (Kondracki, Richling, by Richling 1992) in the surroundings of Chroberz the three types of landscapes are represented - the valley bottoms landscape in Nida Valley, the loessy landscape within Hunch of Wodzisław and chalk - gypsum landscape in Basin of Solec. Apart form the river's valley, which is covered by meadows, the traditional polish agricultural landscape (small plots of different cultures, patches of woods) dominates.

Wigry National Park is situated it the northeastern part of the lowland belt, at the border of three mesoregions. The northern part of investigated area lies within Western Suwałki Lakeland (842.73) and a little part at the east belong to Eastern Suwałki Lakeland (842.72). The western part of the area is covered by forest. At the central and eastern part the mix of meadows, pastures and agriculture land exists. At this fragment of the researched area the glacial moraine landscape dominates. The southern part of the park lies on plain of Augustów (842.74). This is the sander area, mostly covered by forest. In the centre of the park, at the border of the three mentioned mesoregions Wigry lake is situated.

\section{DELIMITATION OF THE LANDSCAPE UNITS}

The maps of landscape units was completed at the scale of $1: 25000$. The formalised method of leading factors (Richling 1979) was implemented. The diversity of three main components has been taken into consideration, which are lithology, relief and land use. The lithological and morphological features are widely used for delimitation of units at the detailed scale. That is because they determined the way of formation of the rest of landscape elements, as the hydrological conditions and soils are. This pattern is modified by the land use, which is the third feature that is taken under consideration. The lithological subtract was classified according to its porosity and wealth of nutritive components. The morphometrical features were the basis of the relief classification. The main aspect of the land use classification was the division into the forest and non-forest areas, taking into consideration the types of forests and the ways the remained areas are used. The landscape units were first delimited using the existing maps of considered components. Later they were subject of field verification. 668 units representing 84 types were delimited within the upland area and 1238 landscape units representing 149 types were delimited within the Wigry National Park. Finally created units were digitalized to allow the use of ArcView for further works.

The classification of the boundary genesis was made, taking on account the type of changing factors. The nine types of boundaries were distinguished. When only one factor changes, the boundary could be of lithological, morphological or land-use origin. When the boundary exist because of change of two factors, it could be morpho- land-use, litho- land-use or litho-morphological. 
The boundaries that characterise themselves with simultaneous change of three investigated factors are called complex ones.

\section{DELIMITATION OF THE HIGHER RANK LANDSCAPE UNITS}

According to Richling (1992) during the process of landscape types delimitation the most important factors are the genesis of their relief and their lithological features. From the legend that served for the delimitation of landscape units at 1:25000 scale, some characteristics typical for every of investigated types of landscape were chosen (see Tab. 1).

Table 1.

Lithological and morphometrical features of landscape units delimited at the scale 1:25000, which are characteristic for units of higher rank - landscape types

\begin{tabular}{|c|c|c|c|}
\hline & $\begin{array}{c}\text { type of } \\
\text { landscape }\end{array}$ & lithology & relief \\
\hline \multirow{3}{*}{ 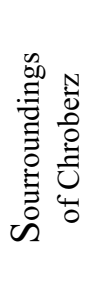 } & loessy & loess & $\begin{array}{l}\text { all existing divisions } \\
\text { exept valleys' bottoms }\end{array}$ \\
\hline & gypsum - chalk & marls, gypsums & $\begin{array}{l}\text { all existing divisions } \\
\text { exept valleys' bottoms }\end{array}$ \\
\hline & $\begin{array}{l}\text { valleys' } \\
\text { bottoms }\end{array}$ & $\begin{array}{l}\text { alluvia, delluvia, turfs } \\
\text { and murshes }\end{array}$ & valleys' bottoms \\
\hline \multirow{2}{*}{ 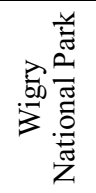 } & glacial & clayey sands, clays & $\begin{array}{l}\text { undulated and hilly } \\
\text { plains, small hills, big } \\
\text { hills, elongated hills }\end{array}$ \\
\hline & fluvioglacial & sands, gravels & plains \\
\hline
\end{tabular}

The landscape units possessing the wanted features were founded on the maps of landscape units made in scale 1:25000. Then the range of their common presence was defined. The latter is the range of different landscape types. If the ranges of the adjacent landscape types created one line, the investigated boundary is linear. If the ranges of the adjacent landscape types penetrated each other, the boundary between them is a belt.

\section{RESULTS}

In the surroundings of Chroberz three boundaries of a higher rank were investigated. The loessy landscape - valleys' bottoms landscape boundary, the valleys' bottoms - the chalk - gypsum landscape boundary and the boundary between chalk - gypsum and loessy landscape. As it could be observed at Fig 1., the investigated boundaries have mostly linear character. 


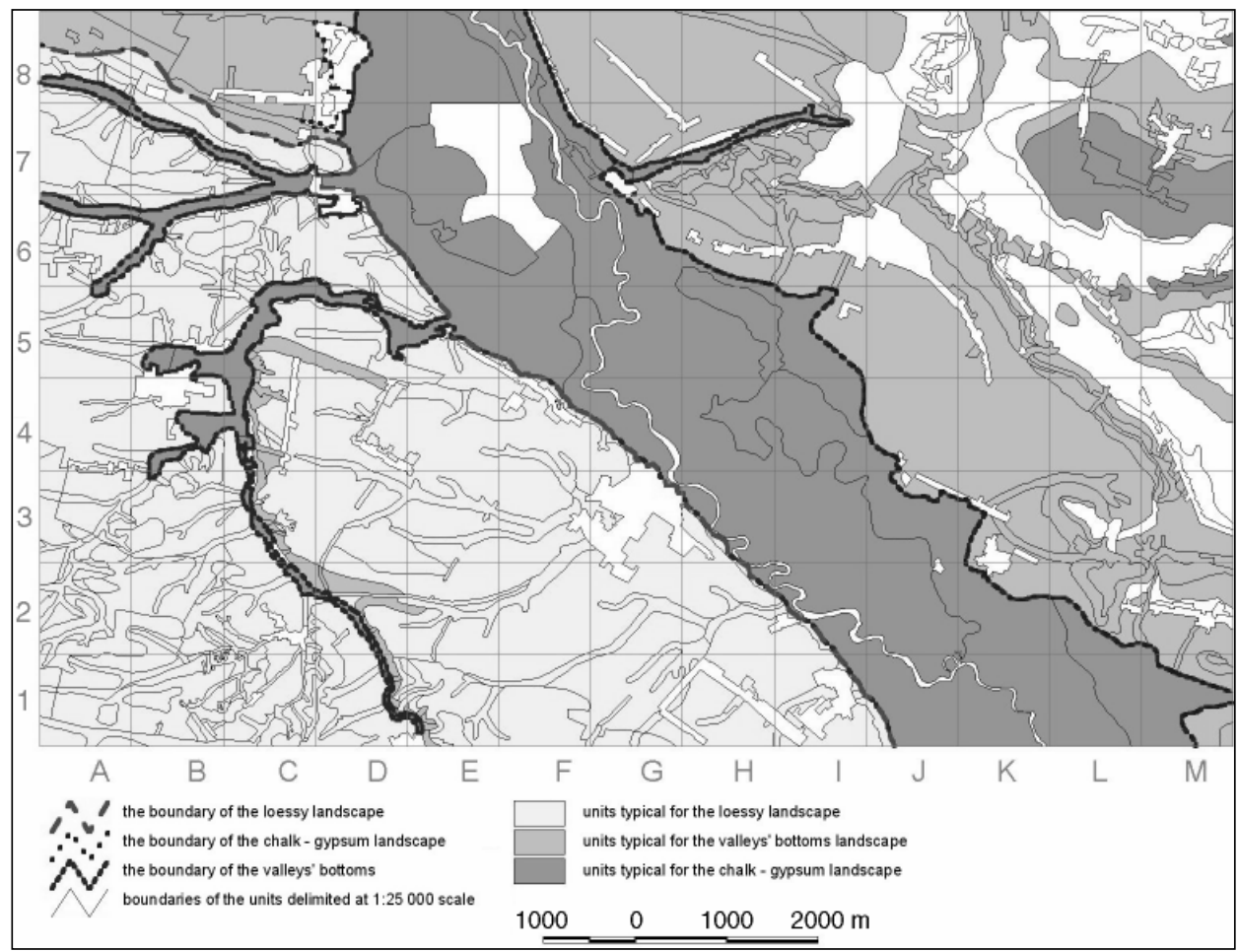

Fig. 1. Boundaries of a higher rank within the upland area.

The boundary between the loessy and the chalk - gypsum landscape is linear on the whole length. $62 \%$ of its length is the result of lithological changes, and within further $25 \%$ of the length the lithology and morphology change. A short part of the investigated boundary is changed by the anthropogenic factor - one built area boundary belongs to the researched group.

The most of the boundary between the loessy and valleys' bottom landscape is linear too. The adjacent landscape types create $8180 \mathrm{~m}$ of the common boundary. Within it there are $1655 \mathrm{~m}$ of built terrains boundaries. The most of lower rank boundaries that belongs to this group are complex ones. The ranges of the adjacent landscape types differ, when the big side valleys that are connected to the main valley cut compact loessy area. Because within the loessy landscape the side valleys are only isolated patches, it is impossible to treat their boundaries as the boundaries of higher rank. Simultaneously at their mouth there are no other boundary, which could be the base of delimitation. In such a case a conventional boundary should be delineated.

The boundary between the valleys' bottom and chalk - gypsum landscape is mostly linear. The ranges of adjacent types of landscape correspond on $11320 \mathrm{~m}$, within this $2830 \mathrm{~m}$ the built areas mark. The majority of landscape boundaries that belong to this group are complex boundaries. There are only 


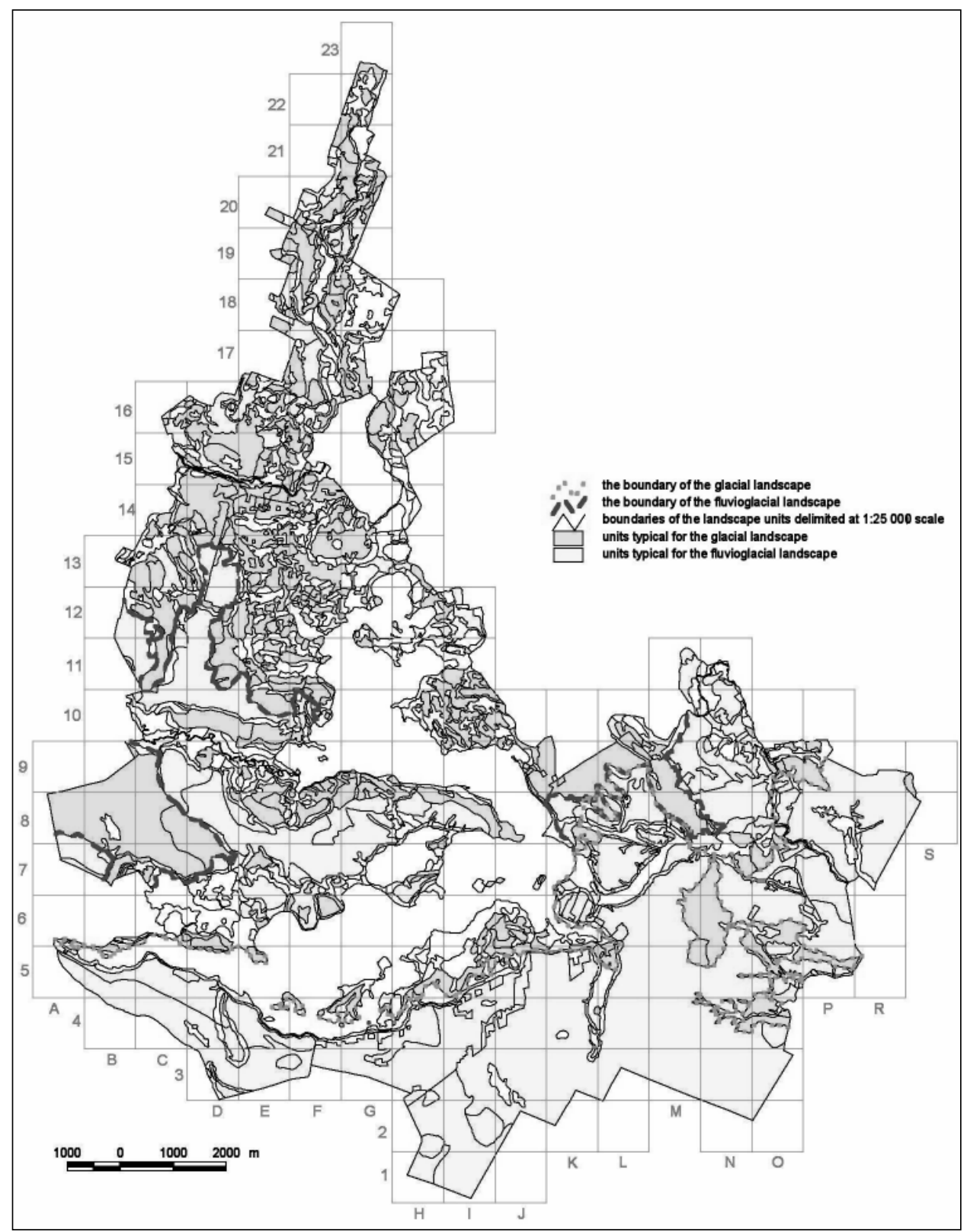

Fig. 2. Boundaries of a higher rank within the lowland area. 
two exceptions from the linear character of the boundaries. The narrow, side valley near Krzyżanowice is to small to let its boundaries to be considered as the boundaries of higher rank. It should be included to the chalk - gypsum landscape. The existence of sandy areas in the northern part of the analysed area results in existence of $700 \mathrm{~m}$ gap between the adjacent landscape units of higher rank. In this case it is proposed to take into consideration the morphological factor, so this part of chalk - gypsum - valleys' bottom boundary refers to the range of valleys' bottom.

The boundaries of the higher rank landscape units in Wigry National Park are different from that within the upland area. As it is presented at Fig. 2., The lower rank units typical for glacial and fluvioglacial landscapes penetrate each other's within the whole researched area. The ranges of investigated landscape types create a belt of different width. At the western part of the park it is nearly $8000 \mathrm{~m}$ wide. The fragment of the investigated boundary has also linear character. It is found east to the Wigry Lake, at the distance of $11320 \mathrm{~m}$. The lower rank boundaries that create the linear section are mainly morphological and complex ones.

\section{DISCUSSION}

The boundaries of a higher rank landscape units within the lowland and upland landscape are of different character. Within the upland landscape the boundaries of a higher rank landscape units are linear. It can be explained by the different geological history of the adjacent terrains. The investigated landscape's types are completely different each to the other due to their lithological characteristics. It should be also underlined, that the boundaries of the valleys' bottoms landscape are of higher rank form the others, as this type of landscape is considered to be a different class (Richling 1992).

Within the lowland landscape the investigated boundary between glacial and fluvioglacial landscapes is mostly the belt of different width. The explanation of this fact is probably also the units' genesis; in this case their lithological substratums are of a similar age and their morphogenesis is complementary.

Within both investigated areas the landscape boundaries of the lower rank proved to be useful in the delimitation of that of a higher rank. However, the chain of the lower rank boundaries ones not means exactly the same, as the boundary of higher rank. Within investigated boundaries only a few conventional segments occurred to be unaavoidable. At the upland area their existence is cause by the necessity of simplifying the valleys' bottoms landscape boundary, and in Wigry National Park the higher rank boundaries have to cross the lake Wigry. 


\section{REFERENCES}

Yurenkov G.I., 1982, Osnownyie problemy fizicheskoi geografii $i$ landshaftowiedieniya [Fundamental problems of physical geography and landscape science; in Russian], Wysshaiya Shkola, Moskva.

Kondracki J., 1988, Geografia fizyczna Polski [Physical geography of Poland; in Polish], PWN, Warszawa.

Richling A., 1979, Z metodyki wydzielania uroczysk w terenach glacjalnych [On the methods of delimitation of ranges in the post-glacial areas; in Polish], Przeglad Geograficzny, 51 (4).

Richling A., 1992, Kompleksowa geografia fizyczna [Complex physical geography; in Polish], PWN, Warszawa.

Wi d a cki W., 1979, Typologia granic geokompleksów w Karpatach [Typology of geocomplexes' boundaries in Carpathian; in Polish], Zeszyty Naukowe Uniwersytetu Jagiellońskiego, Prace Geograficzne, 47, Kraków.

Translated by the author 